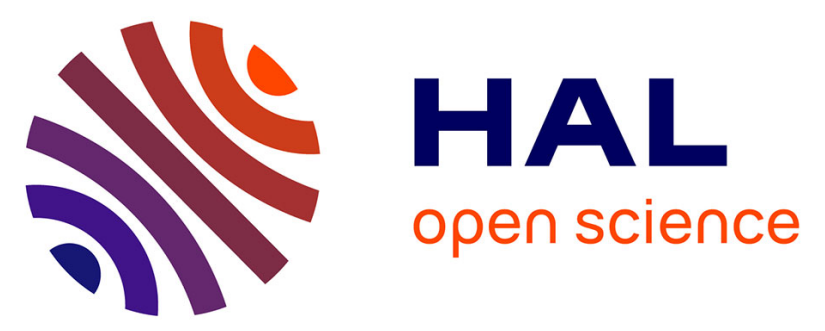

\title{
Influence of raw milk microflora on the characteristics of Swiss-type cheeses. / Evolution of microflora during ripening and characterization of facultatively heterofermentative lactobacilli \\ Y Demarigny, E Beuvier, A Dasen, G Duboz
}

\section{To cite this version:}

Y Demarigny, E Beuvier, A Dasen, G Duboz. Influence of raw milk microflora on the characteristics of Swiss-type cheeses. / Evolution of microflora during ripening and characterization of facultatively heterofermentative lactobacilli. Le Lait, 1996, 76 (4), pp.371-387. hal-00929491

\section{HAL Id: hal-00929491 \\ https://hal.science/hal-00929491}

Submitted on 1 Jan 1996

HAL is a multi-disciplinary open access archive for the deposit and dissemination of scientific research documents, whether they are published or not. The documents may come from teaching and research institutions in France or abroad, or from public or private research centers.
L'archive ouverte pluridisciplinaire HAL, est destinée au dépôt et à la diffusion de documents scientifiques de niveau recherche, publiés ou non, émanant des établissements d'enseignement et de recherche français ou étrangers, des laboratoires publics ou privés. 


\title{
Influence of raw milk microflora on the characteristics of Swiss-type cheeses. I. Evolution of microflora during ripening and characterization of facultatively heterofermentative lactobacilli
}

\author{
Y Demarigny, E Beuvier, A Dasen, G Duboz \\ Station de recherches en technologie et analyses laitières, Inra, \\ BP 89, 39801 Poligny cedex, France
}

(Received 3 November 1995; accepted 5 April 1996)

\begin{abstract}
Summary - During the ripening of raw milk Swiss-type minicheeses, the microbial ecosystem changed, and the quantitative and qualitative levels of microflora evolved constantly. The starter lactic acid bacteria population, ie, thermophilic streptococci and thermophilic lactobacilli, decreased regularly from $10^{8}$ to $10^{5} \mathrm{cfu} / \mathrm{g}$. The propionibacteria and the facultatively heterofermentative lactobacilli, which were in very low numbers before ripening, increased rapidly to reach their final level after 6 weeks (approximately $10^{8} \mathrm{cfu} / \mathrm{g}$ ). The other microflora (Micrococcaceae and enterococci) remained at a subdominant level, or were even undetectable during ripening (coliforms, spores of butyric acid bacteria). Indigenous microflora enumerated in microfiltered milk cheeses evolved identically, except that they started at a lower level. Moreover, the starter bacteria decreased faster. Facultatively heterofermentative lactobacilli seemed to be the most important non-starter lactic acid bacteria. Eighty-eight colonies were isolated on FH agar during ripening, and characterized by means of the API system. The species identified evolved from a great diversity in the beginning to two major subspecies: $L$ paracasei subsp paracasei 1 and 3 . However, the method used to detect this microflora did not allow us to evaluate the nature of the subdominant lactobacilli, although certainly many other species could be isolated.
\end{abstract}

Swiss-type minicheese / microflora / facultatively heterofermentative lactobacilli / bacterial growth

Résumé - Influence de la microflore du lait cru sur les caractéristiques des fromages à pâte pressée cuite. I. Évolution de la microflore durant l'affinage et caractérisation des lactobacilles hétérofermentaires facultatifs. Durant l'affinage, l'écosystème microbien des minifromages à pâte pressée cuite au lait cru évoluait qualitativement et quantitativement. Les streptocoques et lactobacilles thermophiles des levains diminuaient régulièrement de $10^{8}$ à $10^{5} \mathrm{ufc} / \mathrm{g}$. A contrario, les bactéries propioniques et les lactobacilles hétérofermentaires facultatifs, presque indétectables à 20 heures, augmentaient rapidement et atteignaient approximativement $10^{8}$ ufc/g après 6 semaines d'affinage. Les autres flores restaient sous-dominantes (Micrococcaceae, entérocoques) ou indétectables (coliformes, bactéries "butyriques"). Dans des fromages fabriqués au moyen de lait microfiltré, la flore adventice débutait à un niveau plus faible. Les bactéries lactiques du levain diminuaient aussi plus 
rapidement. Parmi ces microflores adventices, les lactobacilles hétérofermentaires facultatifs semblaient plus importants. Au cours de l'affinage, 88 colonies avaient été prélevées sur milieu FH, et caractérisées par méthode API. La diversité d'espèces de cette population diminuait. Ainsi, seules les deux sous-espèces de $\mathrm{L}$ paracasei subsp paracasei 1 et 3 étaient détectables après quelques semaines. Cependant, il n'était pas possible d'évaluer qualitativement et quantitativement les espèces sous-dominantes.

minifromage / fromage à pâte pressée cuite / microflore / lactobacille hétérofermentaire facultatif / croissance microbienne

\section{INTRODUCTION}

Ripening of Swiss-type cheeses is a complex process, involving many biochemical, physicochemical and microbiological changes. However, if there are several results available on biochemical aspects, such as proteolysis (Mocquot, 1979), little information exists about the growth and activity of bacteria during ripening of Swisstype cheeses. Hence, Martley and Crow (1993) studied the interactions between different nonstarter microorganisms, and their effects on the biochemistry of Swisstype cheeses. Accolas et al (1971) demonstrated that heat treatment of the cheese milk influenced the acid production of the starters during the process of Emmental cheese. Veaux et al (1974) noted a slow decrease of the thermophilic streptococci and lactobacilli during ripening; on the contrary, propionibacteria and mesophilic lactobacilli increased strongly. Turner and Thomas (1980), as well as Turner et al (1983), emphasized the importance of thermophilic lactobacilli in the transformation of galactose during pressing of cheese. This is also in agreement with the experiments of Biede et al (1976), who made many Swiss-type cheeses, in order to study the role of Lactobacillus bulgaricus.

Other works deal with the importance of propionibacteria in cheeses. Meriläinen and Antila (1978) specified that it was possible to identify many different species of propionibacteria from Finnish emmental. Fryer and Peberdy (1977), for instance, followed the growth of Propionibacterium shermanii during ripening of Egmont cheese and Swiss-type cheese, when this strain was inoculated in the milk.

It is also interesting to note that an experiment made by ITG (1976) on the influence of micrococci in different cheeses, showed that Emmental cheeses seemed to acquire better taste and opening when the milk was matured with these bacteria.

Among the different microflora present in hard cheeses, we may anticipate that mesophilic lactobacilli can play a major role, mainly because they reach a high number of cells during ripening. Indeed, many workers have already studied these bacteria in Cheddar (Peterson and Marshall, 1990; Jordan and Cogan, 1993; McSweeney et al, 1993), and in Emmental cheese (Sollberger, 1994). These lactobacilli are divided into two groups (Desmazeaud, 1989): the facultatively heterofermentative lactobacilli, such as $L$ paracasei subsp paracasei or $L$ casei, and the strict heterofermentative lactobacilli which include $L$ brevis or $L$ buchneri, for example.

Many experiments pointed out the proteoIytic and the lipolytic activities of these bacteria in cheeses (Khalid and Marth, 1990). However, the facultatively heterofermentative lactobacilli can also participate directly in the production of some major aroma compounds (Thomas, 1987a), such as acetic and formic acids and gas $\left(\mathrm{CO}_{2}\right)$. These bacteria are studied particularly for their ability to transform citrate to produce succinic acid (Hugenholz, 1993). Some authors showed that certain lactobacilli were able to have an antibacterial activity. 
Schillinger and Lücke (1989) described the sakacin A produced by L sake, and Gonzalez et al (1994), the plantaricin C obtained from $L$ plantarum. Finally, mesophilic lactobacilli may interfere with other lactic or non lactic microflora through different interactions (Martley and Crow, 1993; PerezChaia et al, 1994).

The objective of this work was to study the influence of the raw milk microflora on Swiss-type minicheese characteristics. In order to work with the same physicochemical basis, three milks were microfiltered and mixed together. Each retentate, containing the natural microflora, was then added in one different vat containing this milk. A fourth vat was used as reference, since no retentate was incorporated in. This was performed in triplicate at two different seasons.

In part I of this article, we will discuss the main microflora during ripening, including lactic starters, propionibacteria, Micrococcaceae, enterococci, coliforms, yeasts, spores of butyric acid bacteria and facultatively heterofermentative lactobacilli. To our knowledge, no experiment has been done to characterize and identify this latter population in Swiss-type cheese, which was followed qualitatively as well as quantitatively during ripening. Part II of this article will deal with the biochemical and sensory aspects.

\section{MATERIALS AND METHODS}

\section{Cheesemaking}

Cheeses were made according to the experimental protocol presented in figure 1. Raw milks were collected in three plants, located in the Jura mountains at three different altitudes: $915 \mathrm{~m}$ (A), $650 \mathrm{~m}$ (B) and $535 \mathrm{~m}$ (C). Previous works already showed that Comté cheeses made in these plants exhibited distinct aromatic profiles, justifying their choice.

After skimming the milks, the creams were mixed together and pasteurized $\left(85^{\circ} \mathrm{C}, 30 \mathrm{~s}\right)$. Microfiltration was then performed using an
ALFA-LAVAL MSF1 cross-flow microfiltration unit (pore size of ceramic membrane: $1.4 \mu \mathrm{m}$; membrane area: $0.2 \mathrm{~m}^{2}$; flux: $\left.600 \mathrm{Lh}^{-1} \mathrm{~m}^{-2}\right)$. The three retentates (A, B and C) were separated while the three microfiltered milks were mixed together with the pasteurized cream. In three steel vats, approximately $9.4 \mathrm{~kg}$ of this milk was poured, and $1.6 \mathrm{~kg}$ of retentate. Each retentate was readded in order to obtain a bacterial level ranging between $510^{4}$ and $10^{5} \mathrm{cfu} / \mathrm{mL}$, adjusted by the direct epifluorescent filter technique (Dasen et al, 1987). A fourth vat was filled with $11 \mathrm{~kg}$ of milk, but no retentate was readded. Thereafter, the cheese technology described by Bouton et al (1993) was applied. Finally, four minicheeses weighing around $1 \mathrm{~kg}$ were obtained, three made with one different retentate A, B and C (referred to as 'raw' milk cheeses), and one made without raw milk microflora, which was used as reference (T).

Cheesemaking was repeated three times within 2 weeks, in winter and in autumn; thus, 24 cheeses were analyzed. The cheeses were then waxed to avoid smear development. Finally, they were ripened 3 weeks at $14^{\circ} \mathrm{C}, 9$ weeks at $18^{\circ} \mathrm{C}$ (warm room) and 12 weeks at $7^{\circ} \mathrm{C}$ (cold room). This cycle is commonly used in Comté cheese technology (Grappin et al, 1987).

As a result, this protocol made it possible to make cheeses having the same physicochemical characteristics, as shown in table I. Analyses were performed as specified by Bouton and Grappin (1995).

\section{Microbiological analysis}

The cheeses were analyzed at six different periods: $20 \mathrm{~h}$ and $3,6,12,18$ and 24 weeks. At each time, wax was removed. Around $50 \mathrm{~g}$ of cheese were then cut aseptically. Rind ( $3-4 \mathrm{~mm}$ ) was removed. In addition, approximately $5 \mathrm{~mm}$ of cheese was removed all around the sample. However, after each cut, the knife was carefully sterilized before further use, thereby avoiding post-contamination of the sample. The final piece of cheese was placed in a petri dish. Finally, the cheese was rewaxed until further analysis.

Ten $\mathrm{g}$ of a cheese sample were dissolved in a solution of tri-sodium citrate $(4 \% \mathrm{w} / \mathrm{v})$ and adjusted to a final concentration of $1 / 10$ by adding sterile distilled water.

Counts were performed on plate agar by means of a Spiral system apparatus (DS model, 


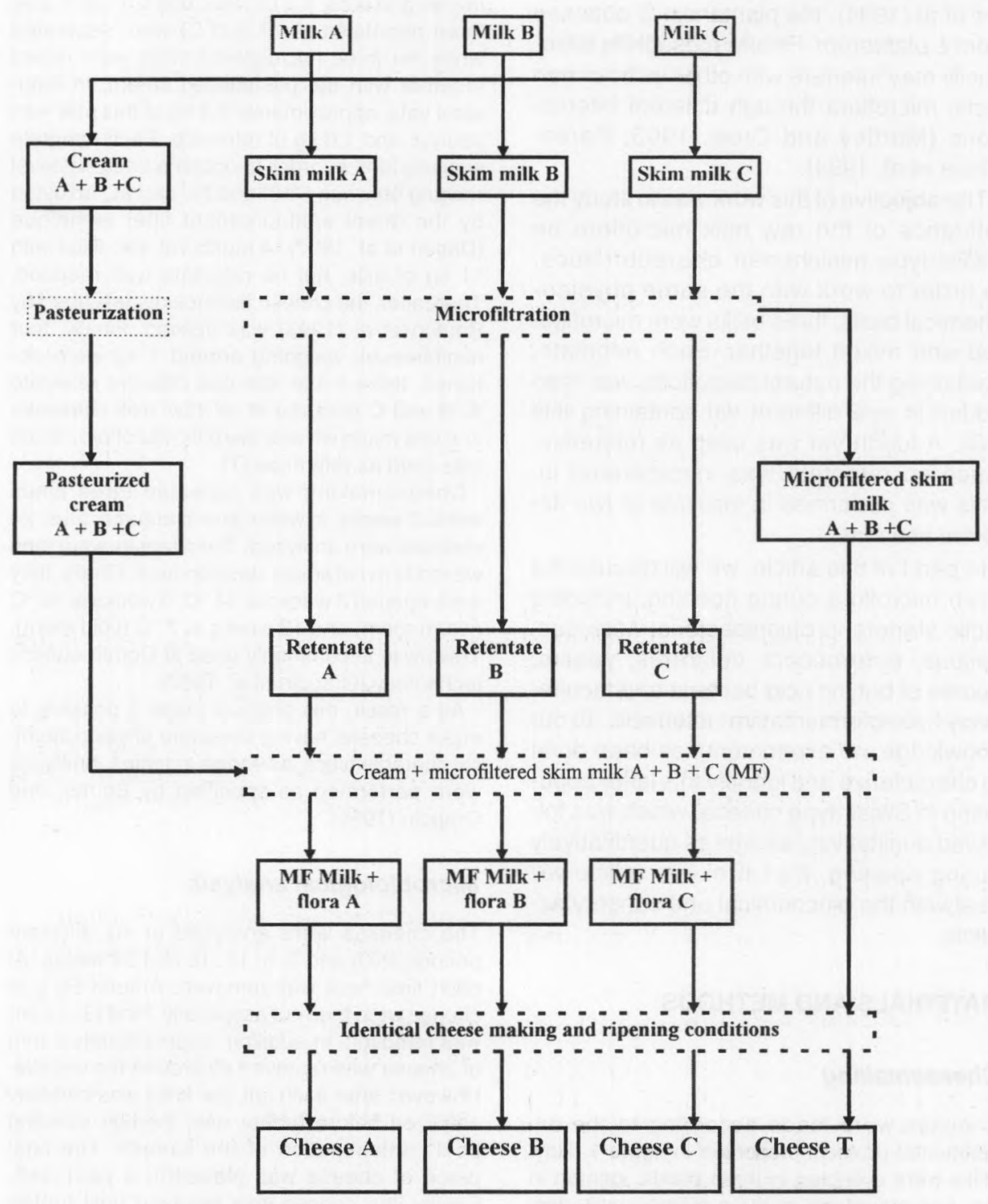

4 cheeses $\times 3$ repetitions $\times 2$ seasons $=24$ cheeses

Fig 1. Principle of cheesemaking.

Schéma de fabrication des fromages. 
Table I. Main physicochemical characteristics of Swiss-type minicheeses made with 'raw' (A, B, C) and microfiltered $(T)$ milk irrespective of the season.

Principales caractéristiques physico-chimiques de minifromages fabriqués à partir de "lait cru " $(A, B, C)$ et de lait microfiltré $(T)$, toutes saisons confondues.

Cheeses

$\begin{array}{llll}T & A & B & C\end{array}$

\begin{tabular}{lccccc}
\hline Dry matter & $20 \mathrm{~h}$ & $64.4 \pm 0.9$ & $64.2 \pm 0.7$ & $64.7 \pm 0.7$ & $64.4 \pm 0.6$ \\
MNFS & $20 \mathrm{~h}$ & $52.6 \pm 1.2$ & $53.2 \pm 1.1$ & $52.9 \pm 1.0$ & $53.1 \pm 1.3$ \\
$\mathrm{pH}$ & $20 \mathrm{~h}$ & $5.28 \pm 0.02$ & $5.27 \pm 0.03$ & $5.25 \pm 0.02$ & $5.26 \pm 0.02$ \\
$\mathrm{~S} / \mathrm{M}$ & 3 weeks & $1.67 \pm 0.23$ & $1.79 \pm 0.12$ & $1.72 \pm 0.23$ & $1.67 \pm 0.22$
\end{tabular}

Each value is the mean of six repetitions. Dry matter: $\mathrm{g} / 100 \mathrm{~g}$ of cheese; MNFS: moisture in nonfat substance $(\mathrm{g} / 100 \mathrm{~g}) ; \mathrm{S} / \mathrm{M}$ : salt on moisture ( $\mathrm{g} / 100 \mathrm{~g}$ of water).

Chaque valeur est la moyenne de six répétitions ; matière sèche en g/100 g de fromage; MNFS : humidité dans le fromage dégraissé ( $g / 100 \mathrm{~g})$; S/M : sel sur eau ( $\mathrm{g} / 100 \mathrm{~g}$ d'eau).

Interscience, St-Nom-la-Bretèche, France). This method allowed a detection limit of $10 \mathrm{cfu} / \mathrm{mL}$ in milk and $100 \mathrm{cfu} / \mathrm{g}$ in cheese. All the measures were made in duplicate. To differentiate the microflora, the following media were used:

- mesophilic aerobic microflora: plate count agar (PCA, Difco); aerobic incubation at $30^{\circ} \mathrm{C}$ for 3 days (AFNOR V08-011, 1978);

- enterocococci: kanamycin esculin agar (KEA, Merck); aerobic incubation at $37^{\circ} \mathrm{C}$ for 2 days (Isenberg et al, 1970);

- Micrococcaceae: mannitol salt agar (MSA Difco); aerobic incubation at $30^{\circ} \mathrm{C}$ for 3 days (Chapman, 1948);

- coliforms: violet red bile agar (VRBA, Difco); aerobic incubation at $30{ }^{\circ} \mathrm{C}$ for $24 \mathrm{~h}$ (AFNOR V08-054, 1993);

- yeasts: glucose chloramphenicol agar; aerobic incubation at $25^{\circ} \mathrm{C}$ for 3 days (FIL/DF 94B, 1991); - propionibacteria: sodium lactate agar and cloxacillin (SLAC); anaerobic incubation at $30^{\circ} \mathrm{C}$ during 6 days (Drinan and Cogan, 1992);

- spores of butyric acid bacteria: Bryant-Burkey broth modified by Bergère (Biokar); anaerobic incubation at $37^{\circ} \mathrm{C}$ during 7 days; spores of butyric acid bacteria were counted in tubes according to the most probable number method (CNERNA, 1987);

- thermophilic streptococci: medium 17 (M17); aerobic incubation at $42^{\circ} \mathrm{C}$ for 3 days (Terzaghi and Sandine, 1975);

- thermophilic lactobacilli: de Man, Rogosa, Sharpe (MRS, Difco); anaerobic incubation at $42^{\circ} \mathrm{C}$ for 3 days (de Man et al, 1960 );

- facultatively heterofermentative lactobacilli: Facultativ Heterofermen-tativen Laktobazillen or $\mathrm{FH}$ agar (Isolini et al, 1990); anaerobic incubation at $38^{\circ} \mathrm{C}$ during 3 days. To increase the selectivity of the medium, nalidixic acid was added (40 mg/L).

\section{Characterization and identification of facultatively heterofermentative lactobacilli}

\section{Lactobacilli isolation}

At each ripening period and for each cheese of the first series of winter milks, six colonies were taken randomly from $\mathrm{FH}$ agar. They were then stored at $-80^{\circ} \mathrm{C}$ in MRS broth with $10 \%(\mathrm{v} / \mathrm{v})$ glycerol for further characterization.

\section{Preliminary characterization of facultatively heterofermentative lactobacilli}

After two purification steps on MRS agar, the characterization of facultatively heterofermentative lactobacilli was performed by means of the following tests: 
- microscopic observation;

- catalase test;

- presence of arginine-dihydrolase;

- growth at $15^{\circ}$ and $45^{\circ} \mathrm{C}$ in MRS broth;

- growth in bactolitmus milk (Difco);

- citrate utilization; this test was performed on calcium citrate agar (KCA, Nickels and Leesment, 1964);

- production of $\mathrm{CO}_{2}$. This last test was the most important because it made it possible to classify the heterofermentative lactobacilli between the two groups.

The strains were incubated in two series of fubes, containing either MRS broth or MRS medium where glucose was replaced by gluconate $(40 \mathrm{~g} / \mathrm{L})$. The production of $\mathrm{CO}_{2}$ was checked by means of Duram bells, placed in the tubes before sterilization. Lactobacilli producing gas from MRS plus glucose and from MRS plus gluconate were classified as obligately heterofermentative, whereas lactobacilli strains producing gas only from MRS plus gluconate were classified as facultatively heterofermentative (Leveau et al, 1991).

\section{Taxonomical characterization}

The second part of the characterization included biochemical tests based on the fermentation of 49 different sugars using an API $50 \mathrm{CHL}$ Lactobacillus system (Biomérieux, Marcy l'Etoile, France). Identification of strains was performed by means of tables from three origins: API, Kandler and Weiss (1986) and Dellaglio et al (1994).

\section{RESULTS}

\section{Identification of some major microflora in A, B, C and T milks before cheesemaking}

Table II shows the different flora enumerated in milks, irrespective of the season, each value listed being the mean of six data. Effectively, no significant differences were found between winter and autumn milks. As expected, the level of the indigenous microflora in 'raw' milks was more than ten times higher than the level measured in reference milks. Indeed, in these latter milks, most of the populations investigated were lower or equal to $10 \mathrm{cfu} / \mathrm{mL}$.
No marked quantitative differences existed between 'raw' milks. Mesophilic aerobic flora reached between 4.56 and $4.85 \mathrm{log}$ (cfu) $/ \mathrm{mL}$, which was expected. Among the populations enumerated in the three milks, propionibacteria and facultatively heterofermentative lactobacilli were detected at very low levels (between 2 and 3 log $(\mathrm{cfu}) / \mathrm{mL}$ ), but quite identical irrespective of the milk.

\section{Comparison of the evolution of the main microflora in 'raw' and microfiltered milk minicheeses}

\section{Lactic acid bacteria of the starter}

Figures $2 \mathrm{a}$ and $\mathrm{b}$ show the average variations of the thermophilic streptococci and thermophilic lactobacilli during ripening knowing that no significant differences were obtained between the three origins of the milk.

At the end of the cheesemaking, the levels of starter microorganisms reached around $10^{8} \mathrm{cfu} / \mathrm{g}$. The comparison of the evolution of the two populations showed no differences between streptococci and lactobacilli. However, the bacteria of the microfiltered milk cheeses decreased more quickly than the bacteria of the 'raw' milk cheeses. At the end of ripening, their levels were $10^{2}$ - to $10^{3}$-fold lower.

It was found that thermophilic streptococci decreased faster in winter cheeses $(-0.092 \pm 0.02 \mathrm{log}(\mathrm{cfu}) / \mathrm{g} /$ week) than in autumn cheeses $(-0.065 \pm 0.02 \mathrm{log}$ (cfu)/ $\mathrm{g} /$ week). This was also noted for thermophilic lactobacilli $(-0.082 \pm 0.02$ vs $-0.063 \pm$ $0.02 \log (\mathrm{cfu}) / \mathrm{g} /$ week).

\section{Other microorganisms}

Propionibacteria followed the same evolutions in 'raw' and microfiltered milk cheeses (fig 3a). In this latter case, however, microfiltration reduced by $10^{2}$ to $10^{3}$ the level of this population in milk (table II), which delayed the growth. As a consequence, propionibacteria in 'raw' milk cheeses reached 

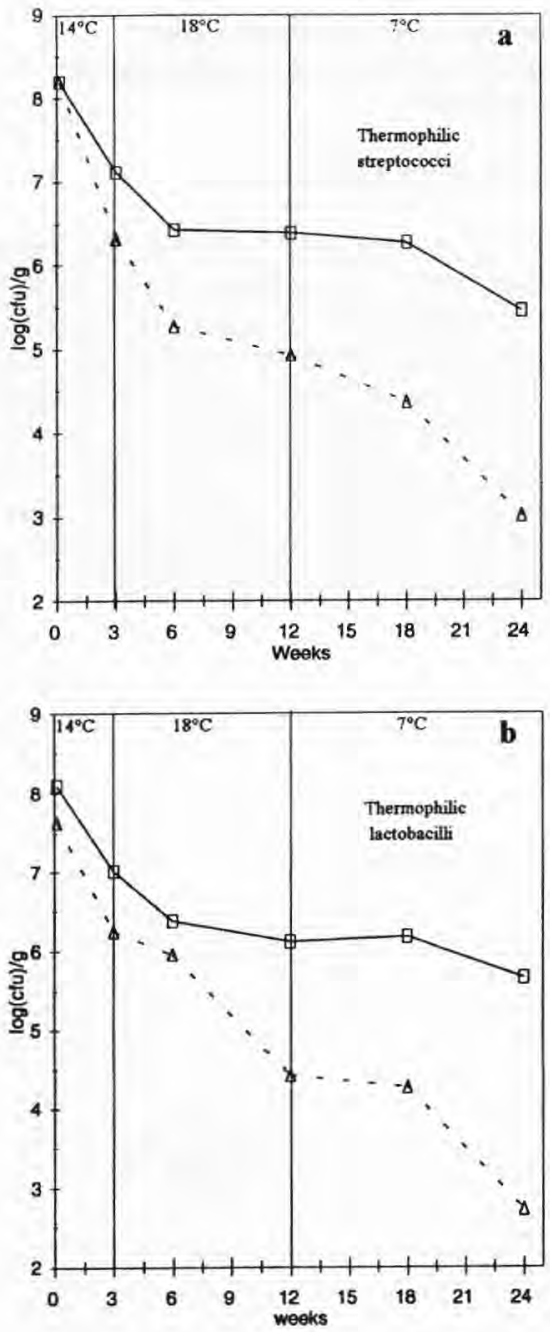

Fig 2. Evolution during ripening of thermophilic streptococci (a) and thermophilic lactobacilli (b) in Swiss-type cheeses made from 'raw' milk ( $\square$ ) and from microfiltered milk $(\Delta)$. Each point of these curves is the mean of 18 values for the 'raw' milk cheeses and six values for the reference cheeses. Évolution au cours de l'affinage des streptocoques thermophiles (a) et des lactobacilles thermophiles (b), dans des fromages à pâte pressée cuite, fabriqués à partir de "lait cru " () et de lait microfiltré ( $\Delta$ ). Chaque point des courbes est la moyenne de 18 valeurs pour les fromages au « lait cru », et de six valeurs pour les fromages de référence.
$10^{8} \mathrm{cfu} / \mathrm{g}$ at the end of warm storage, whereas this level was five times lower in microfiltered milk cheeses. This difference, although already slight, was detected until 18 weeks; thereafter, it disappeared.

The same results were obtained on autumn cheeses, except that microfiltered and 'raw' milk cheeses already reached the same levels at 12 weeks.

Facultatively heterofermentative lactobacilli were found in 'raw' milk cheeses at a higher level than propionibacteria at the beginning of ripening (fig $3 b$ ). Indeed, they reached their maximum level after 6 weeks (around $10^{8} \mathrm{cfu} / \mathrm{g}$ ) as a result of a rapid growth. They remained stable therafter until 24 weeks. In microfiltered milk cheeses, the same tendency was observed, although this population remained at a level ten to 100 times lower than 'raw' milk cheeses, depending on the ripening period.

No significant difference in growth curves was found between the three different 'raw' milk cheeses, or between the two seasons.

Micrococcaceae had a similar behavior after 6 weeks in 'raw' and microfiltered milk cheeses (fig 4a). As previously stated, microfiltration delayed the growth, but this difference was no longer detected after 6 weeks. Cold storage seemed to influence this population, since Micrococcaceae started to decrease after 12 weeks. In autumn cheeses, however, this population decreased slowly from the beginning to the end of ripening, and never exceeded $510^{4} \mathrm{cfu} / \mathrm{g}$.

In 'raw' milk cheeses, enterococci reached their maximum level of $10^{6} \mathrm{cfu} / \mathrm{g}$ (fig $4 b)$ at 6 and 18 weeks. The behavior of this population was irregular during ripening. In microfiltered milk cheeses, the evolution was very weak during the first 6 weeks, and more important thereafter. Nevertheless, they always remained at a level ten- to 100fold lower than in 'raw' milk cheeses, and finally declined after 18 weeks. No difference was detected between 'raw' milk cheeses in winter and autumn. 
It is interesting to note that yeasts can develop in the body of the cheese and not only in the smear (fig 4c). The level remained low, under $10^{5} \mathrm{cfu} / \mathrm{g}$, particularly in the reference cheeses, where yeasts were detected only at 6 weeks.

During the experiment, two other populations were followed: spores of butyric acid bacteria and coliforms. The number of spores of butyric acid bacteria in milks was under $180 / \mathrm{L}$ in milk, which is the detection limit (table II). During the ripening, the number of these bacteria did not exceed $1 / \mathrm{g}$. Coliforms were never detected in cheeses, although $210^{2} \mathrm{cfu} / \mathrm{mL}$ could be counted in the 'raw' milks (table II).

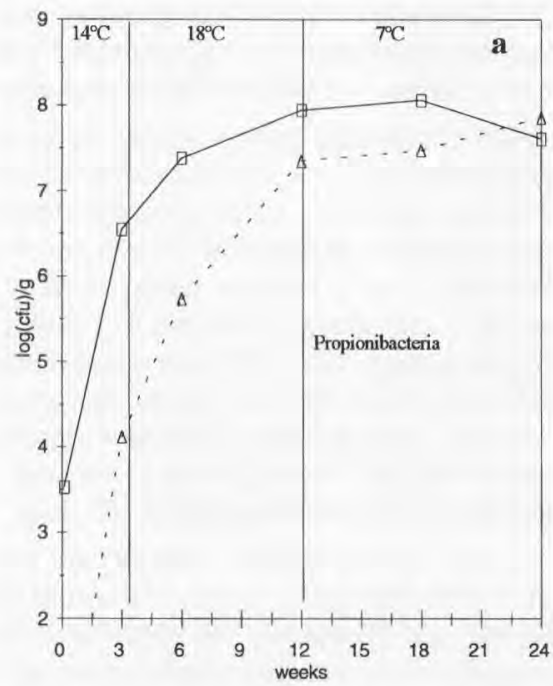

\section{Isolation and characterization of facultatively heterofermentative lactobacilli}

\section{Microscopic identification}

During the experiment, 88 colonies were isolated from $\mathrm{FH}$ medium. All the strains were Gram-positive, catalase-negative and exhibited a similar microscopic morphology (rods), except for a few of them, which were slightly different: long and thin rods, in chains or in clusters (two strains); short and bulky rods, alone or sometimes in clusters (two strains); and coccobacilli-type strains (two strains).

Fig 3. Evolution during ripening of propionibacteria (a) and facultatively heterofermentative lactobacilli (b) in Swiss-type cheeses made from 'raw' milk $(\square)$ and from microfiltered milk $(\Delta)$. Each point on these curves is the mean of 18 values for the 'raw' milk cheeses and six values for the reference cheeses.

Évolution au cours de l'affinage des bactéries propioniques (a) et des lactobacilles hétérofermentaires facultatifs (b), dans des fromages à pâte pressée cuite, fabriqués à partir de "lait cru " () et de lait microfiltré $(\Delta)$. Chaque point des courbes est la moyenne de 18 valeurs pour les fromages au " lait cru ", et de six valeurs pour les fromages de référence. 
Table II. Identification of the main microflora enumerated in milks inoculated with indigenous populations of the retentates.

Identification des principales populations microbiennes des laits de cuve après réincorporation des rétentats.

\section{Milks}

$\begin{array}{llll}T & A & B & C\end{array}$

\begin{tabular}{lcccc}
\hline Mesophilic aerobic microflora & $3.21 \pm 0.41$ & $4.82 \pm 0.15$ & $4.85 \pm 0.10$ & $4.56 \pm 0.15$ \\
Coliforms & $<1$ & $2.23 \pm 0.47$ & $2.08 \pm 0.80$ & $2.43 \pm 0.92$ \\
Micrococcaceae & $<1$ & $3.47 \pm 0.32$ & $3.61 \pm 0.21$ & $3.47 \pm 0.26$ \\
Enterococci & $<1$ & $2.84 \pm 0.32$ & $3.07 \pm 0.41$ & $2.85 \pm 0.50$ \\
Propionibacteria & $1.01 \pm 0.56$ & $2.54 \pm 0.77$ & $2.93 \pm 0.60$ & $2.83 \pm 0.50$ \\
Yeasts & $1.18 \pm 0.89$ & $3.56 \pm 0.19$ & $3.46 \pm 0.42$ & $3.53 \pm 0.33$ \\
Thermophilic streptococci & $1.36 \pm 0.83$ & $3.65 \pm 0.36$ & $3.51 \pm 0.30$ & $3.31 \pm 0.39$ \\
Thermophilic lactobacilli & $<1$ & $2.84 \pm 0.72$ & $2.99 \pm 0.82$ & $2.42 \pm 0.97$ \\
Facult heterof lactobacilli & $<1$ & $2.41 \pm 0.19$ & $2.71 \pm 0.28$ & $2.52 \pm 0.20$ \\
Butyric acid bacteria & $<180$ & $<180$ & $<180$ & $<180$ \\
& & & &
\end{tabular}

Values are expressed in log of colonies forming unit per milliliter of milk, except for butyric acid bacteria: number of cells per liter of milk.

Valeurs exprimées en log d'unités formant colonies par millilitre de lait, à l'exception des bactéries butyriques : nombre de cellules par litre de lait.

\section{Production of $\mathrm{CO}_{2}$}

The $\mathrm{CO}_{2}$ test gave the following results for the 88 strains (table III):

-73 strains $(83 \%)$ were classified in group II as facultatively heterofermentative lactobacilli (Dellaglio et al, 1994);

- ten strains (11\%) belonged to the group III of obligately heterofermentative lactobacill; - five strains (6\%) did not produce gas in the two media. They may belong to the homofermentative lactobacilli group I, to $L$ paracaseisubsp tolerans or to another genus.

The presence of obligately heterofermentative lactobacilli was also found by Isolini et al (1990), who tested 50 strains belonging to group III, and showed that around $8 \%$ were able to grow on $\mathrm{FH}$ medium.

\section{Presence of arginine-dihydrolase}

The 73 strains of group II lactobacilli as well as the five unidentified strains were arginine-dihydrolase-negative whereas the ten remaining strains of group III were argininedihydrolase-positive.

\section{Growth at $15^{\circ}$ and $45^{\circ} \mathrm{C}$}

The 88 strains were able to grow at $15^{\circ} \mathrm{C}$ in MRS broth after 24 to $48 \mathrm{~h}$ of culture. However, only 76 strains grew at $45^{\circ} \mathrm{C}$. As shown in table III, the 12 strains unable to grow at $45^{\circ} \mathrm{C}$ belonged to groups II (9) and III (3).

\section{Growth in bactolitmus milk}

Seventy-two strains belonging to group II of lactobacilli and the five unidentified strains reduced, acidified and coagulated (RAC) litmus milk between 24 to $48 \mathrm{~h}$. On the other hand, eight of the ten strict heterofermentative lactobacilli and one strain of L paracasei subsp paracasei 1 biotype 1 did not modify this medium (INC).

\section{Utilization of citrate}

Twenty-eight of 88 strains were able to transform citrate as energy source. However, 
Table III. Summary of the main characteristics used to classify the different strains of facultatively heterofermentative lactobacilli isolated from Swiss-type cheeses made from 'raw' or microfiltered milk.

Récapitulatif des principaux caractères testés sur les différentes souches de lactobacilles hétérofermentaires facultatifs isolées de fromages à pâte pressée cuite, fabriqués à partir de "lait cru » ou microfiltré.

\begin{tabular}{|c|c|c|c|c|c|c|c|c|c|c|c|}
\hline Strain & Biotype & Group & $\begin{array}{l}\text { No isolated } \\
\text { from milk }\end{array}$ & $\begin{array}{l}\text { No isolated } \\
\text { from cheese }\end{array}$ & \multicolumn{7}{|c|}{ Characteristics } \\
\hline L paracaseisubsp paracasei 1 & 2 & ॥ & 2 & 22 & - & + & 2 & + & $-(3)+(21)$ & - & RAC \\
\hline L paracaseisubsp paracasei3 & & ॥ & 1 & 8 & - & + & 3 & + & $-(1)+(8)$ & - & RAC \\
\hline Lbrevis & & III & 3 & 7 & + & + & 4 & + & $-(3)+(7)$ & + & $\operatorname{RAC}(2) \operatorname{INC}(8)$ \\
\hline Unidentified & & $?$ & 0 & 5 & $-(2)+(3)$ & - & 2 & + & + & - & RAC \\
\hline
\end{tabular}

RAC: strains reducing, acidifying and coagulating the litmus milk; INC: strains inducing no change of the litmus-milk; ADH: presence of arginine-dihydrolase in strains of lactobacilli.

RAC : souches réduisant, acidifiant et coagulant le lait tournesolé; INC, souches ne modifiant pas le lait tournesolé; ADH, présence de l'arginine dihydrolase dans les souches de lactobacilles. 

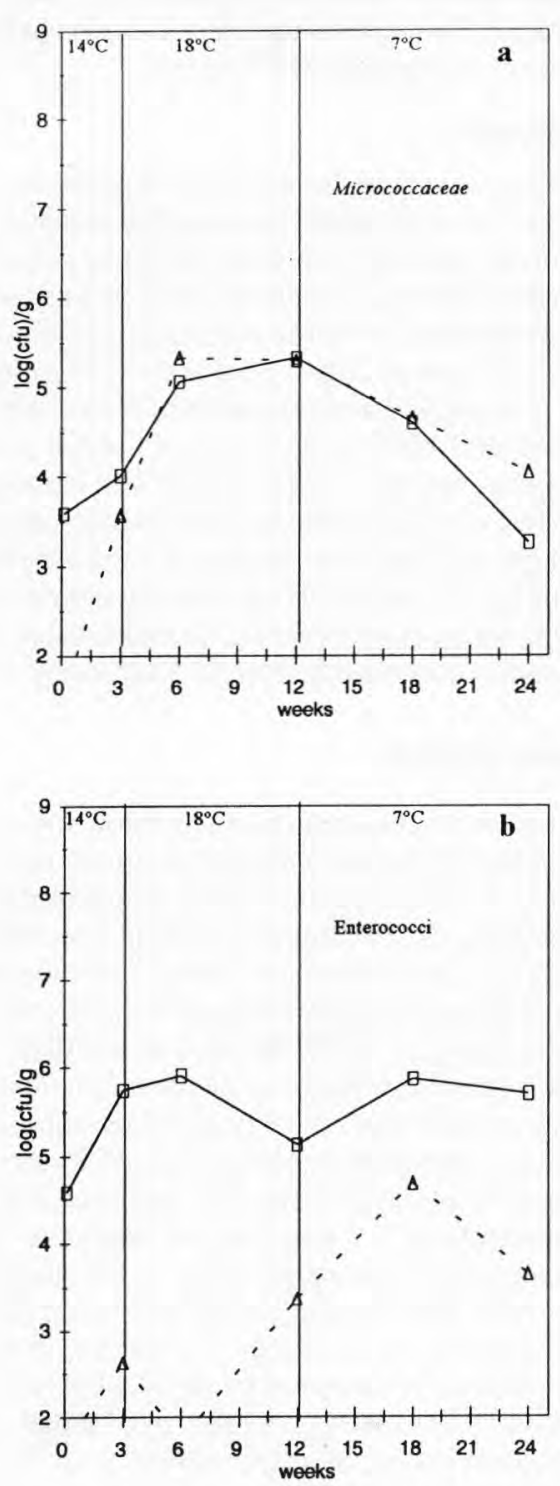

this characteristic seemed to vary during ripening. If nine of 12 strains of the bacteria isolated from milks were cit+, in cheese, this proportion decreased to $6 / 16$ at $20 \mathrm{~h}$ and $4 / 16$ at 3 weeks. After 3 weeks, no more cit+ were detected until 18 weeks.

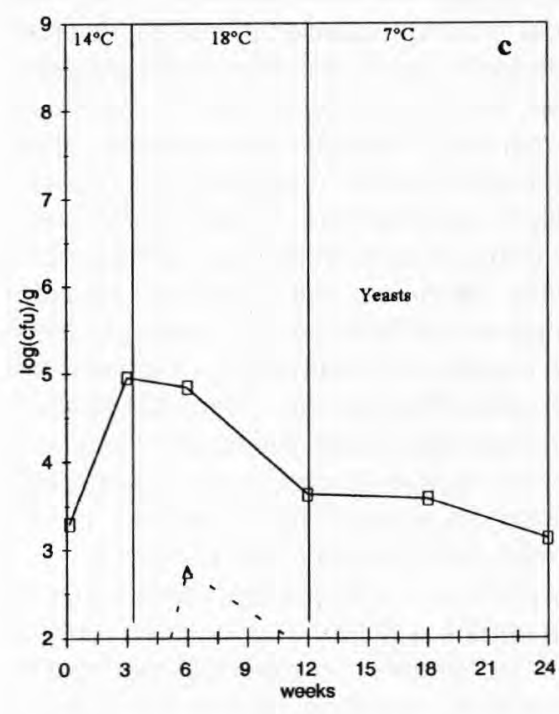

Fig 4. Evolution during ripening of Micrococcaceae (a), enterococci (b) and yeasts (c) in Swisstype cheeses made from 'raw' milk ( $\square$ ) and from microfiltered milk $(\Delta)$. Each point on these curves is the mean of 18 values for the 'raw' milk cheeses and six values for the reference cheeses.

Évolution au cours de l'affinage des Micrococcaceae (a), des entérocoques (b) et des levures (c), dans des fromages à pâte pressée cuite, fabriqués à partir de "lait cru " () et de lait microfiltré $(\Delta)$. Chaque point des courbes est la moyenne de 18 valeurs pour les fromages au "lait cru", et de six valeurs pour les fromages de référence.

However, at the end of ripening, nine of 12 strains were again positive. This result does not take into account the variability of cit+ strains among the cheeses.

\section{Identification}

We were able to identify 83 of the 88 isolated strains. According to the API profiles, 
the following species were found:

- L paracasei subsp paracasei 1 was the most important species identified. Its characteristics were: utilization of ribose, galactose, D-glucose, D-fructose, D-mannose, D-mannitol, $\mathrm{N}$-acetyl-glucosamine, arbutin, esculin, salicin, tagatose, but impossibility to use erythritol, D- and L-arabinose, D- and L-xylose, melibiose, raffinose and xylitol. Moreover, we found two different biotypes: the first one ( 31 strains) fermented $\alpha$-methyl-D-mannoside, which was not the case of the second biotype (24 strains); - L paracasei subsp paracasei 3 was also detected and differed from $L$ paracasei subsp paracasei 1 by its inability to use $\alpha$-methyl-D-glucoside and D-xylose;

- L plantarum was less represented among the strains isolated. This bacteria fermented raffinose, $\alpha$-methyl-D-mannoside, D-arabitol, melibiose, gentiobiose, lactose, sorbitol, amygdalin and cellobiose;

- L rhamnosus was detected once. This strain fermented ribose, galactose, D-glucose, D-fructose, D-mannose, L-sorbose, rhamnose, mannitol, sorbitol, arbutin, salicin, cellobiose, melezitose, but was not able to use L-arabinose, melibiose, raffinose and D-xylose;

- L brevis belongs to group III and used gluconate, D-xylose, L-arabinose, 5-cetogluconate, melibiose. However, it was not able to ferment mannose, arbutin, salicin. mannitol, cellobiose, sorbitol, amygdaline, gentiobiose, trehalose, lactose and sucrose. $L$ brevis is very close to $L$ buchneri, and the differentiation of the two bacteria was only based on the fermentation of melezitose, which was not discriminant enough.

\section{Evolution of the facultatively heterofermentative lactobacilli}

\section{Milks}

L paracasei subsp paracasei 1 and 3 strains were the most important isolated strains $(67 \%)$, but their proportion varied according to the milks. Thus, four of four strains in A milk and three of four in C milk belonged to these two subspecies, whereas in $B$ milk, two strains of $L$ brevis and one of $L$ plantarum were found.

\section{Cheeses}

Figure 5 shows the evolution of composition of the mesophilic lactobacilli population during ripening. The strain diversity noted in the milks was observed until 6 weeks. At 12 weeks, all the strains isolated belonged to $L$ paracasei subsp paracasei 1 ; biotype 1 represented around one-third of this species and biotype 2, two-thirds. After 24 weeks, however, it was possible to isolate in two cheeses some lactobacilli belonging to group III and two strains of $L$ paracasei subsp paracasei3. Thus, even if the growth was stable quantitatively at 6 weeks, the population continued to change qualitatively.

\section{DISCUSSION}

This work was undertaken to follow the evolution of the main microflora during ripening of Swiss-type cheeses. The protocol allowed us to compare cheeses on the same physico-chemical basis. This model was already used by other workers (Bouton and Grappin, 1995; Beuvier et al, 1996). Indeed, minicheeses simulate commercial Swiss-type cheeses although they appear more homogenous (distribution of microflora throughout the cheese, technological parameters). For example, the decrease of temperature during pressing is the same in mini and normal Swiss-type cheeses (Cardenas et al, 1991). Therefore, they constitute an excellent model of what happens in 40 to $50 \mathrm{~kg}$ cheeses, even if extrapolation cannot be made without care.

During this experiment, nine different populations were studied in cheeses and in milks. The comparison of the three cheeses made with microflora from different origins did not reveal any significant difference in growth curve evolution. However, microfiltration led to a late growth of 
mesophilic lactobacilli and propionibacteria, whereas enterococci and yeasts grew at a lower level. Micrococcaceae exhibited the same behavior. Presumably, it may have delayed biochemical transformations in cheese as well. After microfiltration, total count in milk did not exceed $210^{3} \mathrm{cfu} / \mathrm{mL}$. This reduction was not selective (Trouvé et al, 1991), even if most of the populations investigated were under the detection limit after microfiltration. The fact that these microflora were present during ripening means that we used a numeration technique that was not selective enough to detect them in microfiltered milk. However, milks and cheeses were perhaps postcontaminated during the process (Martley and Crow, 1993).

The starter bacteria decreased regularly during ripening to finally reach a level $10^{2}$ times (in 'raw' milk cheeses) to $10^{4}$ times (in reference cheeses) lower than at $20 \mathrm{~h}$; however, they decreased faster in the reference cheese than in the 'raw' milk
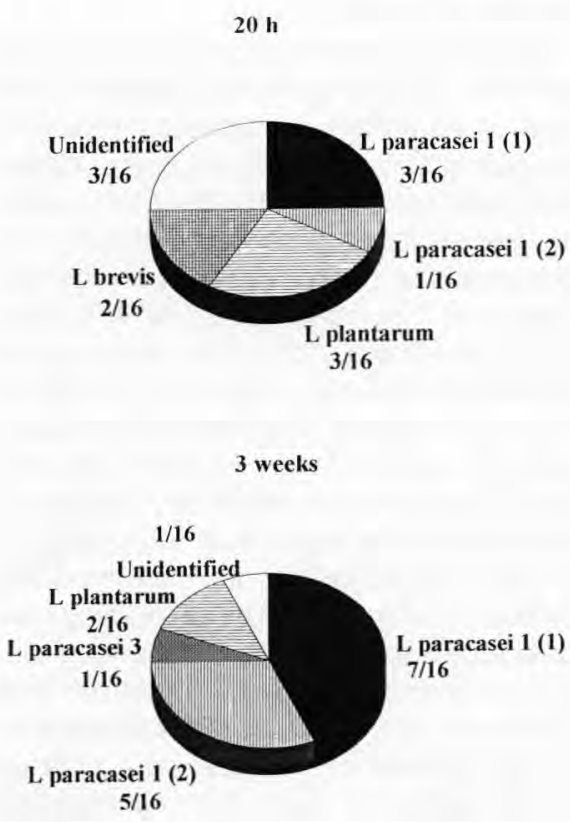

cheeses. In fact, the late growth of the adventitious microflora (mainly facultatively heterofermentative lactobacilli) may have deprived the starter bacteria of some major
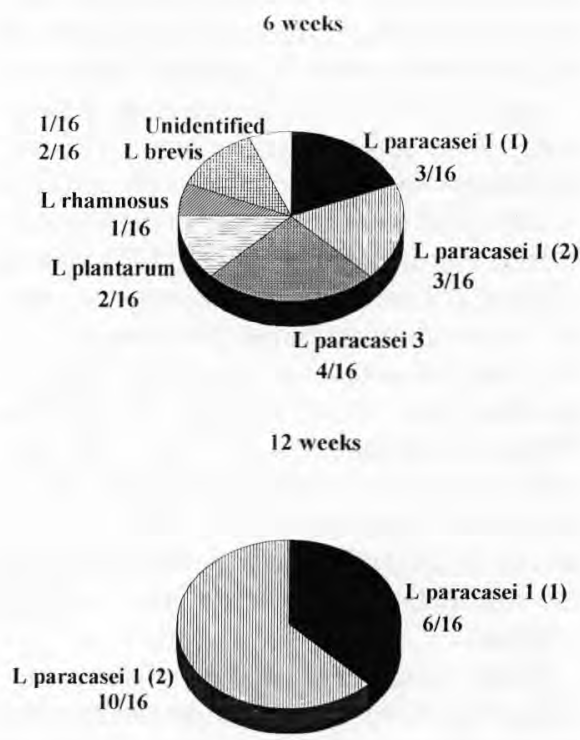

24 weeks

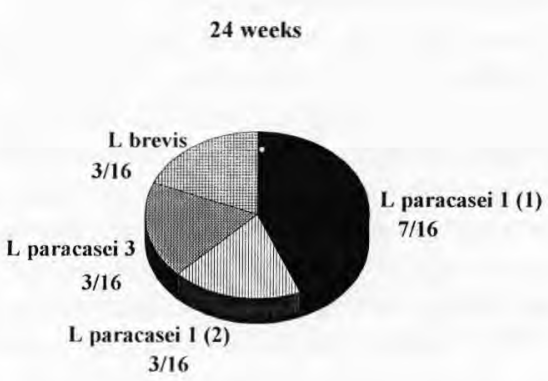

Fig 5. Composition of the mesophilic lactobacilli population.

Composition de la population de lactobacilles mésophiles. 
growth factors essential for their survival. In contrast, we can also argue that nonstarter microflora may have created some specific conditions in 'raw' milk cheeses which prevented the starter bacteria from lysis. These notions emphasize the idea that many interrelations may happen in cheeses such as, in this case, synergy phenomena. However, it is also possible that the milk brought to the cheeses some wild strains related to the starter which were more resistant. In the microfiltered milk, these strains being undetected, they were not able to exhibit a role in the cheese there-after.

Veaux et al (1974) obtained similar results, since at the end of ripening they enumerated thermophilic lactobacilli at $0.1 \%$ of their initial level, while thermophilic streptococci were no longer detected. Beuvier et al (1996) observed a decrease of the starter bacteria population in Swiss-type minicheeses as well. However, these authors reported that after 3 weeks, thermophilic lactobacilli increased again from $710^{5}$ to 7 $10^{6} \mathrm{cfu} / \mathrm{g}$. Adventitious thermophilic lactobacilli may have developed; in fact, this explanation would justify the difference that we noted between winter and autumn cheeses.

Starter bacteria may participate in the modifications of the physico-chemical and biochemical characteristics of the cheese, by casein degradation, and by releasing enzymes from dead cells. However, Thomas (1987b) also suggested that dead cells may be used as nutrients by other microorganisms, like lactobacilli and propionibacteria.

The propionibacteria started their growth at a low or undetectable level, and increased strongly thereafter. They used lactate as an energy source (Langsrud and Reinbold, 1973). Such an evolution was also noticed by Veaux et al (1974) and Beuvier et al (1996). Consequently, this population influenced cheese ripening because of the relations it could establish with other flora. However, they are known to produce acetic and propionic acids, and $\mathrm{CO}_{2}$ as well as flavor compounds, and are essential to obtain typical Swiss-type cheese flavor (Lee et al, 1970).

The total number of propionibacteria increased in the same way in 'raw' and microfiltered milk cheeses, although in this latter case, at a level 100 to 1000 times lower. After 24 weeks, no more differences were detected between the two curves. It means that, even with $10 \mathrm{cfu} / \mathrm{mL}$ in milk, this population was able to reach a high concentration in cheese.

Facultatively heterofermentative lactobacilli and propionibacteria had a similar evolution during ripening, although the former reached their maximum level faster than the latter. Mesophilic lactobacilli were as important in cheese during ripening as propionibacteria, but their influence differed. They have a wide system of proteolytic and lipolytic enzymes (Peterson and Marshall, 1990), and also produce aroma compounds (Hugenholz, 1993). However, these bacteria are not always desirable and may be responsible for split defects (Khalid and Marth, 1990).

The five other populations studied seemed to be of less importance. Some of them were even always undetectable (bacteria producing butyric acid, coliforms). Yeasts were present at a very low but stable level, as well as Micrococcaceae, although this population decreased during ripening in the cold room. The low temperature $\left(7^{\circ} \mathrm{C}\right)$ may have been responsible for this decrease as well as the depletion of the cheese medium in growth factors. Enterococci increased until $10^{6} \mathrm{cfu} / \mathrm{g}$, but were unable to grow higher. The dominant microflora (and especially the starter bacteria at the beginning of ripening) probably inhibit a strong development of enterococci, by consuming residual sugars and because of their high number in cheeses. In fact, we found that cheeses made with $\delta$-gluconolactone (GDL) instead of starters were characterized by higher levels of enterococci (unpublished results). 
Concerning the isolation and the identification of the facultatively heterofermentative lactobacilli, it was possible to select 88 different strains. This population evolved rapidly, to reach a level of $10^{8} \mathrm{cfu} / \mathrm{g}$ after 6 weeks of ripening. From a qualitative point of view, it was possible to isolate many different strains in the cheeses until 6 weeks of ripening. At the end of warm storage, only two types of strains remained: $L$ paracasei subsp paracasei 1, with two biotypes based on $\alpha$-methyl-D-mannoside utilization. It is so possible that this selection was linked with the temperature. In fact, at the end of ripening after 12 weeks at $7{ }^{\circ} \mathrm{C}$, three strains of $L$ paracasei subsp paracasei 3 and three strains of $L$ brevis were isolated. These results differ from those obtained by McSweeney et al (1993), who found several types of lactobacilli in Cheddar cheese made from raw milk. Jordan and Cogan (1993) identified three main bacterial species: $L$ curvatus, $L$ plantarum and L casei.

It is necessary to analyze these conclusions only in terms of tendencies. The low number of colonies isolated from each cheese is not necessarily representative of the composition of the population of facultatively heterofermentative lactobacilli. Moreover, the variability of the strains isolated during ripening can also be explained in part by the random method of isolation, and the choice of the handler to select one colony over another.

The difficulty to identify properly the strains and to differentiate the subspecies accurately are related to the method used to study and analyze the lactobacilli. According to Curk et al (1993), the API system is probably not discriminant enough. These authors noted that some glucides, such as glycerol, D-arabinose and L-xylose, did not allow them to distinguish strains of mesophilic lactobacilli. It would be very interesting in the future to identify the bacteria by means of biomolecular methods. In particular, Dellaglio et al (1994) indicated, for in- stance, that only the use of DNA-DNA hybridization allowed a clear distinction between $L$ brevis and $L$ buchneri.

To reach a level of $10^{8} \mathrm{cfu} / \mathrm{g}$, facultatively heterofermentative lactobacilli must find a source of energy.

Citrate is a potential source of carbon. Fryer (1970) showed that the seven strains of $L$ caseitested, and the nine of ten strains of $L$ plantarum, were cit + . In Emmental cheese, citrate is present at a concentration of $9 \mathrm{mmol} / \mathrm{kg}$ at the beginning of ripening (Sollberger, 1994), and can be degraded by some lactobacilli into aroma compounds such as diacetyl, acetoin, butanediol and acetaldehyde or acetate, formate and $\mathrm{CO}_{2}$ (Hugenholz, 1993).

During our experiment, we noticed that the number of cit+ strains was decreasing, to finally disappear after 3 weeks. Since some cit+ strains were again detected at 24 weeks, we can argue that the number of colonies isolated was too low - four strains per petri dishes - to clearly distinguish a marked tendency in the evolution of the cit+ population.

Nevertheless, this decrease can be correlated with the decrease of the concentration of citrate in cheese observed by Sollberger (1994). In particular, Hugenholz (1993) indicated that, if the citrate-permease which allowed citrate to be carried through the cell wall was a plasmidic enzyme, no experiments were done to prove that the bacteria could lose this characteristic. On the other hand, this author thinks that a cit- variant may develop and become dominant. This former hypothesis could explain our results. Anyway, the citrate concentration does not allow the bacteria to grow at such a high level. Moreover, many strains are not able to use it.

Lactate, another energy source, is used only by some strains of $L$ plantarum (Divies et al, 1994).

Milk sugars (lactose, glucose) are no longer detected in cheese as a result of starter development (Accolas et al, 1978). 
Therefore, we must then imagine other energy sources coming from proteolysis and lipolysis (Martley and Crow, 1993) or autolysis of some other microflora, such as starter bacteria. Thomas (1987b) reported that ribose from nucleic acids may be used by non-starter lactic acid bacteria to support their growth.

Moreover, facultatively heterofermentative lactobacilli have to find nitrogen sources and vitamins essential for their growth. Khalid and Marth (1990) observed that these bacteria possess many proteolytic enzymes; thus, the lactobacilli take an active role in the ripening of the cheeses. However, more information has yet to be acquired to finally appreciate properly the different reactions occurring in the cheeses.

\section{ACKNOWLEDGMENTS}

The authors thank R Grappin for advice during the re-reading of the text, and $N$ Renard and $F$ Dufrene for technical assistance. This project was supported in part by the region council of Franche-Comté (contract no BTH00252), and by Inra (AIP 4926).

\section{REFERENCES}

Accolas JP, Veaux M, Auclair J (1971) Étude des interactions entre diverses bactéries lactiques thermophiles et mésophiles, en relation avec la fabrication des fromages à pâte cuite. Lait 51, 249-272

Accolas JP, Veaux M, Vassal L, Mocquot G (1978) Évolution de la flore lactique thermophile au cours du pressage des fromages à pâte cuite. Lait 58,118 132

AFNOR (1978) Instructions générales pour le dénombrement des microorganismes. Méthodes par numération des colonies croissant à $30^{\circ} \mathrm{C}$. Standard V08-011

AFNOR (1993) Dénombrement des coliformes par comptage des colonies. Standard V08-054

Beuvier E, Berthaud K, Cegarra S, Dasen A, Pochet S, Buscailhon S, Duboz G (1996) Ripening and quality of Swiss-type cheese made from raw, pasteurized or microfiltered milk. Int Dainy J (submitted for publication)

Biede SL, Reinbold GW, Hammond EG (1976) Influence of Lactobacillus bulgaricus on microbiology and chemistry of Swiss-cheese. J Dairy Sci 59, 854-858
Bouton Y, Grappin R (1995) Comparaison de la qualité de fromages à pâte pressée cuite fabriqués à partir de lait cru ou microfiltré. Lait 75, 31-44

Bouton Y, Guyot P, Dasen A, Grappin R (1993) Activité protéolytique de souches de lactobacilles thermophiles isolées de levains et de Comté. I. Validation sur minifromages des techniques de laboratoire. Lait 73, 265-279

Cardenas R, Duboz G, Grappin R (1991) L'investigation en laboratoire de l'ensemble de la fabrication. II. La fabrication. Process 1065, 66-69

Chapman GH (1948) An improved Stone medium for the isolation and testing of food poisoning staphylococci. Food Res 13, 100-105

CNERNA (1987) Recommandations pour établir les grilles de classement des laits en fonction de leur contamination en spores de Clostridia. Rev Lait Fr 469, 32-36

Curk MC, Peladan F, Hubert JC (1993) Caractérisation biochimique des lactobacilles brassicoles. Lait 73 215-231

Dasen A, Piton C, Grappin R, Guerry P (1987) Évaluation de la technique DEFT associèe à un comptage visuel ou à un comptage par analyseur d'images pour la numération de la flore totale du lait cru. Lait $67,77-95$

Dellaglio $F$, de Roissart $H$, Torriani S, Curk MC, Janssens D (1994) Caractéristiques générales des bactéries lactiques. In: Bactéries lactiques, vol 1 ( $\mathrm{H}$ de Roissart, FM Luquet, eds), Lorica, Uriage, 25-70

De Man JC, Rogosa M, Sharpe ME (1960) A medium for the cultivation of lactobacilli. J Appl Bacteriol 23, 130-135

Desmazeaud M (1989) Les germes utiles. Chap 1, Les bactéries lactiques. Ir. Les groupes microbiens d'intérêt laitier, Cepil, Paris, France, 9-61

Divies C, Frey L, Hubert JC, de Roissart H (1994) Metabolism of other carbon sources by lactic acid bacteria. In: Bactéries lactiques, vol 1 ( $\mathrm{H}$ de Roissart, FM Luquet, eds) Lorica, Uriage, 291-307

Drinan FD, Cogan TM (1992) Detection of propionic acid bacteria in cheese. J Dairy Res 59, 65-69

FIL/IDF (1991) Laits et produits laitiers. Dénombrement des levures et des moisissures. Comptage des colonies à $25^{\circ} \mathrm{C}$. Standard $94 \mathrm{~B}$

Fryer TF (1970) Utilization of citrate by lactobacilli isolated from dairy products. J Dairy Res 37, 9-15

Fryer TF, Peberdy MF (1977) Growth of propionibacteria in Swiss and Egmont cheeses. NZ J Dairy Sci Technol 12, 133-134

Gonzalez B, Arca P, Mayo B, Suarez JE (1994) Detection, purification and partial characterization of plantaricin C, a bacteriocin produced by a Lactobacillus plantarum strain of dairy origin. Appl Environ Microbiol $60,2158-2163$

Grappin R, Berdagué JL, Dasen A, Jeunet R (1987) Affinage et qualité du Gruyère de Comté. I. Protocole expérimental. Caractérisation des conditions d'affinage et des ateliers de fabrication. Lait 67, 219-235

Hugenholz T (1993) Citrate metabolism in lactic acid bacteria. FEMS Microbiol Rev 12, 165-178 
Isenberg HD, Goldberg D, Sampson J (1970) Laboratory studies with a selective enterococcus medium. Appl Microbiol 20, 443-446

Isolini D, Grand M, Glättli H (1990) Selektivmedien zum Nachweis von obligat und fakultativ heterofermentativen Laktobazillen. Schweiz Milchw Forschung 19, 57-59

ITG (1976) Les microcoques en fromagerie. Etude ZS/76-1/BC

Jordan KN, Cogan TM (1993) Identification and growth of non starter lactic acid bacteria in Irish Cheddar cheeses. Irish J Agric Food Res 32, 47-55

Kandler O, Weiss N (1986) Section 14: Regular, nonsporing gram-positive rods. In: Bergey's Manual of Systematic Bacteriology, vol 2 (PH Sneath, NS Mair, ME Sharpe, JG Holt, eds), Williams \& Wilkins, Baltimore, MD, USA

Khalid NM, Marth EH (1990) Lactobacilli. Their enzymes and role in ripening and spoilage of cheese: a review. J Dairy Sci 73, 2669-2684

Langsrud T, Reinbold GW (1973) Flavor development and microbiology of Swiss-type cheeses, a review. III. Ripening and flavor production. J Milk Food Technol 36, 593-609

Lee SY, Vedamuthu ER, Washam CJ, Reinbold GW (1970) Diacetyl production by Propionibacterium shermanii in milk cultures. Can J Microbiol 16, 1231-1241

Leveau JY, Bouix M, de Roissart H (1991) Méthodes d'évaluation des différentes microflores à incidence technologique. Chap 3: La flore lactique. In: Techniques d'analyse et de contrôle dans les industries agro-alimentaires (CM Bourgeois, JY Leveau, eds) Tec et Doc Lavoisier, Paris, France

Martley FG, Crow VL (1993) Interaction between nonstarter microorganisms during cheese manufacturing and ripening. Int Dairy $J 3,461-483$

McSweeney PLH, Fox PF, Lucey JA, Jordan KN, Cogan TM (1993) Contribution of the indigenous microflora to the maturation of Cheddar cheese. Int Dairy J3, 613-634

Meriläinen V. Antila M (1978) Les bactéries propioniques du fromage d'Emmental finlandais. Brèves Commun, XX Congr Int Lait, Paris, France, 773-774
Mocquot G (1979) Reviews of the progress of dairy science: Swiss-type cheeses. J Dairy Res 46, 133-160

Nickels C, Leesment $H$ (1964) Method for differentiation and quantitative determination of starter bacteria. Milchwissenschaft 19, 374-378

Perez-Chaia A, De Saad AMS, Pesce de Ruiz Holgado A, Oliver $G$ (1994) Influence of propionate on growth and fermentative activity of lactobacilli. J Appl Bacteriol 77, 134-139

Peterson SD, Marshall RT (1990) Non starter lactobacilli in Cheddar cheese: a review. J Dairy Sci 73, 13951410

Schillinger U, Lücke FH (1989) Antibacterial activity of Lactobacillus sake isolated from meat. Appl Environ Microbiol 55, 1901-1906

Sollberger H (1994) Parameter zur Früherfassung des Nachgärungsrisikos beim Emmentaler-Käse. Schweiz Milchw Forschung 23, 20-24

Terzaghi BE, Sandine WE (1975) Improved medium for lactic streptococci and their bacteriophages. Appl Microbiol 29, 807-813

Thomas TD (1987a) Acetate production from lactate and citrate by non-starter bacteria in Cheddar cheese. NZJ Dainy Sci Technol 22, 37-47

Thomas TD (1987b) Cannibalism among bacteria found in cheese. NZJ Dainy Sci Technol 22, 215-219

Trouvé E, Maubois JL, Piot M, Madec MN, Fauquant J, Rouault A, Tabard J, Brinkman G (1991) Rétention de différentes espèces microbiennes lors de l'épuration du lait par microfiltration en flux tangentiel. Lait 71, 1-13

Tumer KW, Thomas TD (1980) Lactose fermentation in Cheddar cheese and the effect of salt. NZ J Dainy Sci Technol 15, 265-276

Turner KW, Morris HA, Martley FG (1983) Swiss-type cheeses. II. The role of thermophilic lactobacilli in sugar fermentation. NZJ Dainy Sci Technol 18, 117-123

Veaux M, Accolas JP, Vassal L, Auclair J (1974) Evolution des bactéries lactiques et des bactéries propioniques au cours de la fabrication et de l'affinage du gruyère. Brèves Commun, XIX Congr Int Lait, New Dehli, India, 458-459 